\title{
PENGARUH MODEL PROBLEM BASED LEARNING BERBASIS LEMBAR KERJA PESERTA DIDIK TERHADAP KEMAMPUAN PEMAHAMAN KONSEP MATEMATIS
}

\author{
Tiara Afridiani ${ }^{1)}$, Slamet Soro ${ }^{2)}$, Ayu Faradillah ${ }^{3)}$ \\ ${ }^{1)} U H A M K A$, Cipinang, Jakarta; tiaraafdiani@gmail.com \\ 2)UHAMKA, Binong Permai, Tangerang; slamet.soro@yahoo.co.id \\ 3)UHAMKA, Cipondoh Makmur, Tangerang; ayufaradillah@uhamka.ac.id
}

\begin{abstract}
Abstrak
Penelitian ini bertujuan untuk mengetahui terdapat atau tidaknya pengaruh model problem based learning berbasis lembar kerja peserta didik terhadap kemampuan pemahaman konsep matematis peserta didik di SMP 174 Jakarta. Penelitian ini merupakan penelitian kuantitatif dan menggunakan metode penelitian eksperimen jenis quasy experiment dengan tipe the nonequivalent posttest only control group design. Populasi penelitian ini mencakup seluruh peserta didik kelas VII SMP Negeri 174 Jakarta pada semester genap tahun pelajaran 2018/2019. Sampel yang diteliti sebanyak 71 peserta didik dari kelas VII-D dan VII-G. Teknik pengambilan sampel menggunakan metode cluster random sampling. Dalam penelitian ini teknik pengumpulan data menggunakan instrumen kemampuan pemahaman konsep matematis. Instrumen terlebih dahulu di uji coba di SMP Negeri 160 Jakarta untuk 66 peserta didik pada kelas VIII-C dan kelas VIII-D. Penelitian ini menggunakan uji normalitas, data yang diperoleh kelas eksperimen dan kelas kontrol berdistribusi normal. Sehingga dilakukan uji hipotesis menggunakan uji t menghasilkan t-hitung sebesar 1,9521 yang mengakibatkan tolak $\mathrm{H}_{0}$ pada taraf signifikansi $5 \%$ dengan effect size sebesar 0,5343 yang tergolong sedang. Hasil penelitian ini dapat disimpulkan bahwa terdapat pengaruh model problem based learning berbasis lembar kerja peserta didik terhadap kemampuan pemahaman konsep matematis dengan kriteria sedang.
\end{abstract}

Kata Kunci: Model Problem Based Learning, LKPD, Kemampuan Pemahaman Konsep Matematis.

\section{Abstract}

This study aims to investigate the effect of the problem-based learning model and students' worksheets on the ability to understand mathematical concepts of learners. This is a quantitative study using a quasi-experimental with the nonequivalent type 
posttest only control group design. The population are all students of class VII SMP 174 Jakarta in the 2018/2019 school year. The samples are 71 students from classes VII-D and VII-G. The sampling technique is a cluster random sampling. Data collected using instruments of understanding mathematical concepts. The distribution of experimental and the control class are normal. Hypothesis testing produces a t-test of 1.9521 which results in a decline in $\mathrm{H} 0$ at a significance level of $5 \%$ with an effect size of 0.5343 which is classified as moderate. The results of this study indicate that there is an effect of the problem-based learning model based on student worksheets on the ability to understand mathematical concepts with moderate criteria..

Keywords: Problem Based Learning Model, LKPD, Mathematical Concept Understanding Ability.

\section{Pendahuluan}

Matematika merupakan salah satu ilmu pendidikan yang memerlukan pikiran untuk memahami, mengingat serta mengenal tentang aturan-aturan yang sudah ada dan harus dipatuhi guna menguasai materi yang akan dipelajari. Matematika berupa gabungan dari pemecahan masalah, penalaran dan pembuktian, komunikasi, membuat koneksi, dan menggunakan representasi (Kritzer, 2009:410). Berdasarkan gabungan tersebut matematika juga berkaitan dengan pemahaman konsep yang diharapkan dapat membantu peserta didik dalam menjelaskan dan menyelesaikan permasalahan berdasarkan gagasan/aturan yang sesuai. Pemahaman dalam matematika digunakan sebagai tolak ukur keberhasilan tujuan pengajaran sehingga ketidakmampuan untuk memahami sebuah konsep akan mengakibatkan ketidakmampuan peserta didik dalam memahami materi berikutnya yang didasarkan pada konsep tersebut (Krisnawati, 2018; Zuchri, 2017). Pernyataan tersebut menjelaskan bahwa pentingnya kemampuan pemahaman konsep matematis bagi peserta didik untuk menunjang keberhasilan pada tujuan pembelajaran. Jika konsep dasar yang diterima peserta didik salah/tidak sesuai maka sulit untuk memahami konsep berikutnya. Pengetahuan konsep akan mempermudah peserta didik dalam memahami pelajaran dan menyelesaikan permasalahan dengan konsep yang sesuai. Kemampuan pemahaman konsep dikatakan rendah saat terjadi kesalahan analisis yang menunjukkan bahwa peserta didik kurang dalam pengetahuan dan prosedur untuk menemukan hasil akhir yang sesuai (Latha, 2007; Tambychik \& Meerah, 2010; Star, 2005; Johnson \& Schneider,

Euclid, p-ISSN 2355-1712, e-ISSN 2541-4453, Vol. 7, No. 1, pp. 1- 76

CLembaga Penelitian Universitas Swadaya Gunung Jati (UGJ), Cirebon. 
2014). Pernyataan tersebut menunjukkan bahwa kemampuan pemahaman konsep matematis masih rendah sehingga ketika proses pembelajaran diharapkan guru dapat membimbing peserta didik terhadap indikator yang sesuai untuk membangun kemampuan pemahaman konsep matematis peserta didik.

Menyikapi permasalahan-permasalahan tersebut, guru memerlukan model pembelajaran terhadap kemampuan pemahaman konsep matematis peserta didik. Model Problem Based Learning (PBL) sebagai salah satu model pembelajaran yang dapat digunakan. Pemilihan model PBL dikarenakan model ini menekankan pada keterlibatan peserta didik secara langsung. Komalasari berpendapat bahwa model PBL merupakan pembelajaran yang menggunakan masalah dunia nyata sebagai suatu konteks bagi peserta didik untuk belajar tentang cara berpikir kritis dan ketrampilan pemecahan masalah, serta untuk memperoleh pengetahuan dan konsep yang esensial dari materi pelajaran (Laelasari dan Ratnasari, 2014:15). Penggunaan masalah dunia nyata, diharapkan peserta didik dapat memahami konsep dan memperoleh pengetahuan yang sesuai untuk menyelesaikan permasalahan. The PBL is active learning that makes it possible students to become aware of and determine their problem solving abilities and learning needs to be able to make knowledge operative and do group work in dealing with real life problems. In addition, group discussions in such PBL groups seem to have a positive influence on the students' interest in the subject matter. (Akınoğlu \& Tandoğan, 2007; Dolmans \& Schmidt, 2006; Choo, Rotgans, Yew \& Schmidt, 2011). Pernyataan tersebut diartikan bahwa pembelajaran aktif pada PBL memungkinkan peserta didik untuk dapat menyelesaikan masalah dengan menggunakan pengetahuan yang dilakukan secara kerja kelompok dalam menangani masalah kehidupan nyata. Selain itu, pendapat lain mengatakan PBL may be implemented as one of the student centred learning approaches. That is, learning begins with a problem to be solved, and the problem is posed is such a way that students need to gain new knowledge before they can solve the problem. Rather than seeking a single correct answer, students interpret the problem, gather needed information, identify possible solutions evaluate options, and present conclusions (Temel, 2014; Padmavathy \& Mareesh, 2013). Berdasarkan pernyataan tersebut diketahui bahwa model PBL merupakan model pembelajaran yang melibatkan peserta didik untuk berperan aktif. Sumber belajar yang dapat menunjang atau membantu peserta didik dalam membangun kemampuan 
pemahaman konsep matematis salah satunya yaitu adalah lembar kerja peserta didik (LKPD). LKPD berisi tugas-tugas yang harus dikerjakan untuk melatih peserta didik dalam menguasai materi pelajaran secara maksimal sesuai dengan tujuan pembelajaran. One way of guiding instruction can refer to the use of scaffolds like process worksheets (Merrienboer, 1997; Choo, Rotgans, Yew \& Schmidt, 2011). Hal tersebut berarti bahwa LKPD dapat digunakan sebagai salah satu cara untuk membimbing peserta didik dalam proses pembelajaran. Penggunaan LKPD, diharapkan peserta didik mampu membangun kemampuan pemahaman konsep matematis untuk menyelesaikan permasalahan matematika sesuai dengan konsep-konsepnya.

\section{Metodologi Penelitian}

Metode yang digunakan pada penelitian ini yaitu quasi experiment. Desain penelitian yang digunakan pada penelitian ini menggunakan the nonequivalent posttest only control grup desain yang artinya penelitian ini terdapat 2 kelas yaitu kelas ekperimen dan kelas kontrol namun tidak mengunakan tes awal (pre tes) tetapi menggunakan tes akhir (pos tes).

1. Populasi dan Sampel

Populasi penelitian ini yaitu seluruh peserta didik kelas VII SMP Negeri 174 Jakarta pada semester genap tahun pelajaran 2018/2019. Sampel yang diambil sebanyak dua kelas, sampel dipilih secara acak dan terbentuk menjadi 2 kelompok yaitu kelas VII G sebagai kelas eksperimen dan kelas VII D sebagai kelas kontrol.

2. Desain Penelitian

Adapun desain penelitian ini yang sejalan dengan Arikunto (2013: 126) sebagai berikut:

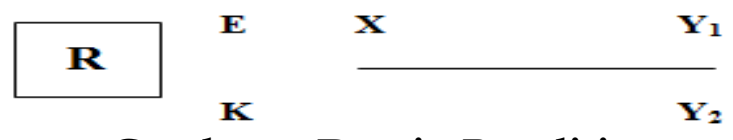

Gambar 1. Desain Penelitian

Keterangan:

$\mathrm{R} \quad$ : Acak Kelas

E : Kelas eksperimen

K : Kelas kontrol

$\mathrm{X} \quad$ : Perlakuan kelas (model PBL berbasis LKPD)

$\mathrm{Y}_{1} \quad$ : Kemampuan pemahaman konsep matematis kelas eksperimen

$\mathrm{Y}_{2} \quad$ : Kemampuan pemahaman konsep matematis kelas kontrol

Euclid, p-ISSN 2355-1712, e-ISSN 2541-4453, Vol. 7, No. 1, pp. 1- 76

CLembaga Penelitian Universitas Swadaya Gunung Jati (UGJ), Cirebon. 


\section{Hasil dan Pembahasan}

Hasil yang diperoleh pada pengujian persyaratan penelitian ini yaitu :

Tabel 1. Hasil Uji Normalitas Setelah Perlakuan

\begin{tabular}{cccccc}
\hline Kelas & $\begin{array}{c}\text { Jumlah } \\
\text { Sampel }\end{array}$ & $\begin{array}{c}\text { Taraf } \\
\text { Sig. }\end{array}$ & $L_{\text {hitung }}$ & $L_{\text {tabel }}$ & Kesimpulan \\
\hline Eksperimen & 36 & 0,05 & 0,1166 & 0,1477 & $\begin{array}{c}\text { Data Berdistribusi } \\
\text { Normal }\end{array}$ \\
Kontrol & 35 & 0,05 & 0,1326 & 0,1498 & $\begin{array}{c}\text { Data Berdistribusi } \\
\text { Normal }\end{array}$ \\
\hline
\end{tabular}

Dari Tabel 1 terlihat bahwa kelas eksperimen dan kelas kontrol memiliki data yang berdistribusi normal pada uji instrumen. Selanjutnya dilakukan uji homogenitas untuk mengetahui bahwa kedua kelas tersebut memiliki varians yang homogen.

Tabel 2. Hasil Uji Homogenitas Setelah Perlakuan

\begin{tabular}{cccccc}
\hline Kelas & $\begin{array}{c}\text { Jumlah } \\
\text { Sampel }\end{array}$ & Varians & $F_{\text {hitung }}$ & $F_{\text {tabel }}$ & Kesimpulan \\
\hline Eksperimen & 36 & 13,0000 & 1,65 & 1,77 & $\begin{array}{c}\text { Varians kedua } \\
\text { kelas Homogen }\end{array}$ \\
\hline
\end{tabular}

Dari Tabel 2 didapat bahwa varians kedua kelas tersebut homogeny. Selanjutnya, melakukan perhitungan uji-t untuk mengetahui terdapat atau tidaknya pengaruh model PBL berbasis LKPD terhadap kemampuan pemahaman konsep matematis dan uji effect size untuk mengetahui besarnya pengaruh.

Tabel 3. Hasil Uji-t dan Effect Size

\begin{tabular}{ccc}
\hline Aspek & Uji-t & Effect Size \\
\hline $\begin{array}{c}\text { Kemampuan Pemahaman } \\
\text { Konsep Matematis }\end{array}$ & $1,9521>1,6715$ & 0,5343 \\
\hline
\end{tabular}

Dapat dilihat hasil dari Tabel 3 bahwa $\boldsymbol{t}_{\text {hitung }}=1,9521>1,6715=$ $\boldsymbol{t}_{\text {tabel }}$. Hal ini menyebabkan $H_{0}$ ditolak, artinya terdapat pengaruh pembelajaran dengan menggunakan model PBL berbasis LKPD terhadap kemampuan pemahaman konsep matematis peserta didik. 
Perhitungan effect size yang diperoleh yaitu sebesar 0,5343, artinya besar pengaruh tergolong sedang.

Pembahasan pada penelitian ini yaitu :

\section{a. Kontribusi Model Problem Based Learning (PBL) Berbasis Lembar Kerja Peserta Didik (LKPD)}

Pembelajaran dengan menggunakan model PBL berbasis LKPD dilakukan selama 6 kali pertemuan. Proses pembelajaran menggunakan model PBL berbasis LKPD pada materi segiempat dan segitiga. Materi yang diajarkan berbeda tiap pertemuannya. Pembelajaran dengan menggunakan model PBL terdiri dari 5 tahapan yaitu 1) orientasi peserta didik pada masalah; 2) mengorganisasi peserta didik untuk belajar; 3) membimbing pengalaman individual atau kelompok; 4) mengembangkan dan menyajikan hasil karya; dan 5) menganalisis dan mengevaluasi proses pemecahan masalah. Setiap tahapan pada model PBL digunakan dalam menyelesaikan permasalahan di LKPD. Keterkaitan model PBL dengan LKPD terletak pada tahapan membimbing pengalaman individual atau kelompok. Pada tahap tersebut peserta didik dibimbing melalui LKPD untuk mengumpulkan informasi tentang materi segiempat dan segitiga secara mandiri bersama kelompoknya. Hal tersebut sejalan dengan pendapat dari Sulistyani (2016: 25) yang mangatakan bahwa LKPD dapat melatih peserta didik belajar secara mandiri dan lebih melibatkan peserta didik dalam pembelajaran. Pendapat tersebut dapat disimpulkan bahwa peserta didik dapat melatih sikap mandirinya dengan penggunaan LKPD. Sehingga terlihat bahwa terdapat kontribusi antara model PBL dengan LKPD.

\section{b. Kontribusi Model Problem Based Learning (PBL) terhadap Kemampuan Pemahaman Konsep Matematis}

Pembelajaran dengan model PBL terhadap kemampuan pemahaman konsep matematis peneliti gunakan untuk penelitian ini. Penggunaan model PBL diharapkan mampu membentuk dan membangun kemampuan pemahaman konsep matematis peserta didik. Sesuai dengan tahapan model PBL menurut Nasir (2016:7) yaitu 1) orientasi peserta didik pada masalah; 2) mengorganisasi peserta didik untuk belajar; 3) membimbing pengalaman individual atau kelompok; 4) mengembangkan dan menyajikan hasil karya; dan 5) menganalisis dan mengevaluasi proses pemecahan masalah. Tahapan-

Euclid, p-ISSN 2355-1712, e-ISSN 2541-4453, Vol. 7, No. 1, pp. 1- 76

CLembaga Penelitian Universitas Swadaya Gunung Jati (UGJ), Cirebon. 
tahapan tersebut dapat membantu peserta didik dan guru dalam menggunakan model pembelajaran yang lebih menarik lagi untuk menunjang tujuan pembelajaran yang maksimal. Dan sesuai juga dengan indikator kemampuan pemahaman konsep matematis menurut Faradisa (2017:85) yaitu 1) menyatakan ulang sebuah konsep; 2) mengklasifikasikan objek menurut sifat-sifat tertentu (sesuai dengan konsepnya); 3) memberi contoh dan bukan contoh dari konsepnya; 4) menggunakan, memanfaatkan dan memilih prosedur atau operasi tertentu; dan 5) mengaplikasikan konsep atau algoritma pada pemecahan masalah. Kelima indikator tersebut digunakan dalam membantu peserta didik untuk membangun kemampuan pemahaman konsep matematis. Keterkaitan model PBL dengan kemampuan pemahaman konsep matematis terletak pada tahapan menganalisis dan mengevaluasi proses pemecahan masalah. Pada tahap ini melibatkan peserta didik untuk mengevaluasi hasil diskusi dengan mengaplikasikan konsep sebagai keterampilannya dalam memecahkan masalah, dimana mengaplikasikan konsep merupakan indikator dari kemampuan pemahaman konsep matematis. Seperti yang dikatakan oleh Utrifani \& Betty dalam Rerung, Sinon \& Widyaningsih (2017:49) bahwa pada model PBL melibatkan peserta didik untuk memecahkan suatu masalah melalui tahap metode ilmiah sehingga peserta didik dapat mempelajari pengetahuan yang berhubungan dengan masalah tersebut serta memiliki keterampilan untuk memecahkan masalah. Pernyataan tersebut menjelaskan bahwa pemecahan masalah pada model PBL diperlukan keterampilan peserta didik dalam menganalis dan mengevaluasi sesuai dengan kemampuan pemahaman konsep matematis. Sehingga terlihat bahwa terdapat kontribusi antara model PBL dengan kemampuan pemahaman konsep matematis peserta didik.

\section{c. Kontribusi Perindikator Kemampuan Pemahaman Konsep Matematis dengan LKPD}

Pembelajaran dengan LKPD terhadap kemampuan pemahaman konsep matematis digunakan peneliti untuk melakukan penelitian ini. Dengan penggunaan LKPD diharapkan peserta didik dapat membangun dan membentuk kemampuan pemahaman konsep matematis sesuai dengan indikatornya. Terdapat 5 indikator kemampuan pemahaman konsep matematis yaitu yaitu 1) menyatakan ulang sebuah konsep; 2) mengklasifikasikan objek menurut sifat-sifat tertentu (sesuai dengan konsepnya); 3) memberi contoh dan bukan contoh dari konsepnya; 4) 
menggunakan, memanfaatkan dan memilih prosedur atau operasi tertentu; dan 5) mengaplikasikan konsep atau algoritma pada pemecahan masalah. Setiap indikator tersebut dapat membangun dan membentuk kemampuan pemahaman konsep matematis peserta didik. Keterkaitan LKPD dengan kemampuan pemahaman konsep matematis terletak pada indikator memberi contoh dan bukan contoh dari konsepnya. Sedangkan pada LKPD terdapat contoh pengerjaan dari segiempat dan segitiga yang sesuai dengan konsepnya. Seperti pendapat dari Rizki, Kamid, \& Saharuddin (2018:23) yang mengatakan bahwa pada LKPD perlu diberikan contoh-contoh pengerjaan dan penyelesaian. Dari pernyataan tersebut disimpulkan bahwa dalam penggunaan LKPD perlu diberikan contoh-contoh dengan harapan dapat membantu peserta didik dalam proses pengerjaan. Sehingga terlihat bahwa terdapat kontribusi antara LKPD dengan kemampuan pemahaman konsep matematis.

\section{Simpulan dan Saran}

Berdasarkan hasil penelitian, pengelolaan dan pengujian hipotesis dapat disimpulkan bahwa terdapat pengaruh signifikan dari pembelajaran yang menggunakan model PBL berbasis LKPD terhadap kemampuan pemahaman konsep matematis. Pembelajaran yang membangun kemampuan pemahaman konsep matematis peserta didik, lebih baik dengan penggunaan model PBL berbasis LKPD daripada penggunaan model PBL tanpa berbasis LKPD. Hal tersebut terlihat dari rata-rata skor postes pada kelas eksperimen yaitu 12,5 dengan simpangan baku 3,6056 dan kelas kontrol yaitu 11 dengan simpangan baku 2,8076. Hasil perhitungan hipotesis statistik dengan uji-t menunjukkan bahwa $t$ hitung $=1,9521>1,6715=t$ tabel yang berarti $H_{0}$ ditolak pada taraf signifikansi $\alpha=0,05$. Pengaruh penelitian ini sebesar 0,5343 atau tergolong sedang.

Saran pada penelitian ini antara lain:

a. Guru disarankan dapat menggunakan model PBL berbasis LKPD dalam pembelajaran matematika karena dengan pembelajaran ini dapat berpengaruh dalam membangun kemampuan pemahaman konsep matematis peserta didik pada materi segiempat dan segitiga.

b. Segala keterbatasan yang ada dalam penelitian ini dapat dijadikan bahan referensi untuk penelitian lebih lanjut. Dan harapannya lebih 
mempersiapkan hal-hal saat melakukan penelitian seperti menyiapkan LKPD dan perangkat pembelajaran lainnya.

\section{Daftar Pustaka}

Akınoğlu, Orhan., \& Ruhan Özkardeş Tandoğan. (2007). The Effects of Problem-Based Active Learning in Science Education on Students' Academic Achievement, Attitude and Concept Learning. Turkey: Eurasia Journal of Mathematics, Science \& Technology Education, 3(1), 71-81.

Arikunto. (2013). Prosedur Penelitian Suatu Pendekatan Praktik. Yogyakarta: Rineka Cipta.

Choo, Serene S.N., Jerome I. Rotgans., Elaine H. J. Yew., \& Henk G. Schmidt. (2011). Effect of Worksheet Scaffolds on Student Learning in Problem Based Learning. Singapore: Springer.

Dolmans, D. H. J. M., \& Schmidt, H. G. (2006). What do we know about cognitive and motivational effects of small group tutorials in problem-based learning? Advances in Health Sciences Education, 11(4), 321-336.

Faradisa, Insania. (2017). Pengaruh Model Pembelajaran Kooperatif Make A Match Terhadap Pemahaman Konsep Matematika Siswa Kelas VIII SMP Negeri 1 SIMAN Ponorogo. Ponorogo: Universitas Muhammadiyah Ponorogo.

Johnson, Bethany Rittle., \& Michael Schneider. (2014). Developing Conceptual and Procedural Knowledge of Mathematics. Oxford University Press.

Krisnawati, Endang. (2018). Desain Tugas untuk Mengidentifikasi Proses Kognitif Siswa dalam Memahami Konsep Pecahan. Surabaya: Jurnal Euclid, Vol 5 No 2.

Kritzer, Karen L. (2009). Barely Started and Already Left Behind: A Descriptive Analysis of the Mathematics Ability Demonstrated by Young Deaf Children. USA: Oxford University Press.

Laelasari., \& Ira Ratnasari. (2014). Perbandingan Kemampuan Pemahaman Matematis Antara Siswa yang Menggunakan Model Pembelajaran Problem Based Learning (PBL) dan Model Pembelajaran Group Investigation (Gi) Pada Siswa Kelas VIII SMP Negeri 2 Jalaksana. Cirebon: Jurnal Euclid, Vol 1 No.1. 
Latha, Maheswari Narayanan. (2007). Analysis of Error in Addition and Subtraction of Fraction among Form 2. Kertas Projek Sarjana Pendidikan. Universiti Malaya.

Merrie“nboer, J. J. G. V. (1997). Training complex cognitive skills: A fourcomponent instructional design model for technical training. Englewood Cliffs, NJ: Educational Technology.

Nasir, Muhammad. (2016). Effektivitas Model Pembelajaran Berbasis Masalah (Problem Based Learning)Terhadap Kemampuan Pemecahan Masalah Siswa Pada Pelajaran Matematika. Baruh Jaya: Muallimuna jurnal madrasah ibtidaiyah.

Padmavathy, R. D., \& Mareesh. K., (2013). Effectiveness of Problem Based Learning In Mathematics. India: Internasional Multidiscriplinary eJournal.

Rerung, Nensy., Iriwi L.S. Sinon., \& Sri Wahyu Widyaningsih. (2017). Penerapan Model Pembelajaran Problem Based Learning (PBL) Untuk Meningkatkan Hasil Belajar Peserta Didik SMA Pada Materi Usaha dan Energi. Papua: Jurnal Ilmiah Pendidikan Fisika Al-BiRuNi, 06 (1).

Rizki, Hedia., Kamid., \& Saharuddin. (2018). Pengembangan Lembar Kerja Peserta Didik (LKPD) Matematika Untuk Siswa Tunarugu (SDLB-B). Jambi: Jurnal Riset Pendidikan Matematika Vol 1, No 2.

Star, J. R. (2005). Reconceptualizing procedural knowledge. Journal for Research in Mathematics Education, 36, 404-411.

Sulistyani, Niluh. (2016). Pengembangan Lembar Kegiatan Siswa (LKS) Bangun Ruang Sisi Datar Berbasis PBL. Yogyakarta: Jurnal Matematika Vol 6, No 1 .

Tambychik, Tarzimah., Thamby Subaha Mohd Meerah. (2010). Students' Difficulties in Mathematics Problem-Solving: What do they Say?.Malaysia: Science Direct.

Temel, Senar. (2014). The Effects of Problem Based Learning On Pre Service Teachers' Critical Thinking Dispositions and Perceptions of Problem Solving Ability. Turkey: South African Journal of Education 34(1).

Zuchri, Saefudin. (2017). Manipulatif Berbantuan Geogebra untuk Membantu Pemahaman Siswa dalam Menyelesaikan Word Problem Kelas 7 SMP. Cirebon: Jurnal Euclid Vol 4 No 2. 